\title{
OVERGENERALIZATION IN SINGULAR/PLURAL NOUNS AND SUFFIXED NOUNS OF IELTS COURSE STUDENTS
}

\author{
Gharizi Matiini \\ Insititut Teknologi Indonesia \\ Email: ziedisanasini@yahoo.com \\ DOI: http://dx.doi.org/10.17509/bs_jpbsp.v16i2.4478
}

\begin{abstract}
This study aims to investigate the morphological overgeneralization of IELTS students. It focuses on the singular/plural nouns and suffixed nouns that are overgeneralized by those students. Three students are chosen as the participants of the study by collecting their writing exercises. Three writing texts are gathered taken from several weeks and materials. The writings are analyzed by sorting the nouns they produced and categorizing them according to the singular/plural nouns and suffixed nouns. The results reveal that the students over extended the rules of singular/plural nouns and suffixed nouns. However, recovery occurs very varied in both singular/plural nouns and suffixed nouns. They tend to be better in mentioning singular/plural nouns, yet they are being selective and careful in writing suffixed nouns. In conclusion, even though the language learners can mark their overgeneralization, it is still difficult for them to recover their errors. It is recommended here that longitudinal study that has more time to examine students recovery from overgeneralization can be conducted for the further study to give more detail evidence in students' overgeneralizations.
\end{abstract}

Keywords: overgeneralization, singular/plural nouns, suffixed nouns

\begin{abstract}
Abstrak
Penelitian ini bertujuan untuk menyelidiki overgeneralisasi dari morfologi siswa IELTS. Fokus studi ini terletak pada kata benda tunggal dan jamak dan kata benda akhiran yang memiliki overgeneralisasi yang telah dibuat para pelajar. Tiga siswa terpilih sebagai pasrtisipan dengan mengumpulkan latihan menulis mereka. Tiga teks hasil para pelajar tersebut telah diambil selama beberapa minggu selama waktu belajar. Tulisan tersebut kemudian dianalisa dengan cara menyortir kata benda, kemudian mengkategorikan mereka sesuai dengan kata benda tunggal dan jamak serta kata benda akhiran. Hasil studi ini menunjukkan bahwa siswa lebih banyak membuat overgenerlisasi pada kata benda tersebut disbanding kata-kata lainnya. Namun, mereka sangat bervariasi dalam memperbaiki kesalahan overgeneralisasi mereka. Mereka cenderung lebih baik dalam menyebutkan kata benda tunggal dan jamak, namun mereka menjadi selektif dalam menulis kata benda akhiran. Kesimpulannya, meskipun pembelajar bahasa dapat menandai generalisasi yang berlebihan mereka, masih sulit bagi mereka untuk memperbaiki kesalahan mereka. Penelitianlongitudinal sangat disarankan untuk studi lebih lanjut dengan membuat lebih banyak waktu untuk memeriksa perbaikan kesalahan dari overgeneralisasi yang dilakukan oleh peserta didik. untuk memberikan bukti lebih detail di overgeneralisasi pada peserta didik.
\end{abstract}

Kata kunci: overgeneralisasi, kata benda tunggal dan jamak, kata benda akhiran 


\section{INTRODUCTION}

Overgeneralization is often defined as the learners' own way to make rules of the second language because of their incapability to differentiate between L1 and L2 rules. "Overgeneralization is the phenomenon when one overextends one rule to cover instances to which that rule does not apply" (Saidan, 2011, p.185). The rules of language they make are often inappropriate and inapplicable in the real linguistic rules. Hence, many learners produce the weird words in their speech. "Overgeneralization allows the learners to make a learning task more manageable to themselves by extending a language rule to linguistic norms where it is not appropriate" (Harakchiyska, 2011, p.116). In other words, the learners consciously plan to create their own linguistics rules even though they are aware that the rules they made are possibly wrong.

Overgeneralization may appear in different aspects of linguistics such as semantic, syntactic, morphological, or behavioral (Saidan, 2011, p.186). It can occur in many ways according to the background knowledge of the learners that can possibly influence the learner to be confused of certain patterns. It usually comes when both L1 and L2 rules have different form of pattern in the same kind of knowledge. For example in morphological patterns, the learners typically overgeneralize the '-ness' rule, producing noun constructions from the adjective words such as the lessness as the same with happiness and kindness. Cabrera and Zubizarreta (2005) discovered that "the errors made by the learners are motivated by their lack of knowledge of the lexico-semantic features that determine which word classes alternate in a sentence" (p.15). It has given to their incomplete L2 knowledge that makes them often use different word class.

In relation to the morphological overgeneralization, Tyler and Nagy (1987) found that such overgeneralization is defined as relational knowledge. "This is the knowledge (or perception) that two words are morphologically related to each other; that is, they share a common lexical base (e.g., argue $\sim$ argument as opposed to off offer or depart department)" (p.3). The failure of relational knowledge may happen when the learners cannot recognize the appropriate position of those suffix rules and they decide to 'relate' it with other rules that are more familiar with them. It is also applied with the singular and plural noun when the learners are sometime flustered with countable and uncountable nouns. They commonly cannot recognize between uncountable noun of money and countable moneys. It finally result to the innovation of the new rules with I have some moneys in my wallet.

Previous studies also found that the learners are very aware of making overgeneralization. According to Baker's Paradox (1979) children are exposed to linguistic structures that they overgeneralize, and it demonstrates that they capture some general structure of the language. It means that the learners get full understanding when they have overgenerelized their speech. From that understanding, they start to find the structure that they think it is appropriate. "Language learners recover from these overgeneralizations, in spite of the lack of negative evidence and the infinity of allowable constructions that remain unheard" (Onnis \& Robert, 2002, p.1). Learners' ability to overcome their overgeneralization is part of the language acquisition process that they build to comprehend the L2 completely.

Overgeneralization, as one of the aspect of interlanguage, has received many attentions in second language acquisition. It is considered as the most significant reasons why the second language learners make inappropriate speech pattern in their interlanguage. Data from research studies on second language acquisition (Ellis, 1994; Gass \& Selinker, 2008; Lightbown \& Spada, 2006) showed that: 1.) children who learn their first language tend to 
overgeneralize grammatical patterns; and 2.) overgeneralization of $\mathrm{L} 2$ rules affects the second language production of young learners. It means that it is such a common phenomenon for the L2 learners to make mistakes in their speech because the knowledge they got from L1 influences greatly on their L2 production. Moreover, the difference between L1 and L2 rules makes them difficult to apply L2 without making any mistakes. Therefore, overgeneralization occurs as the alternative way for the learners to avoid their confusion between both rules. They usually overextend the patterns and create their own L2 speech that are not appropriate to be applied. As a result, they are being trapped by mistakes and errors.

On the other hand, having many inappropriate patterns in the L2 speech does not mean that the language learners cannot repair their own rules to be the appropriate ones. Studies on children language acquisition have proven that those kids substantively understand when they overextend in their speech, especially the rules in part of speech such as nouns and verbal words. Bowerman (1982) pointed out that most previous studies of the acquisition of morphology have been concerned with children's understanding of the morphological markers of themselves. "A child has the ability to recover from overgeneralization errors" (Li,1996, p. 2). They have the signal to know whether the speech they produce is correct or wrong. From that moment, they try to recover their errors.

However, rather than the studies of overgeneralization in children's language acquisition, there is only a little study examining the second language learners' recovery from the overgeneralization which means that it has not been proven yet for other language users including the language learners. Moreover, previous studies also emphasize more to the grammatical rules than the rules of morphological patterns. In particular, the studies of overgeneralization in nouns such as derivational nouns, inflectional nouns, singular/plural nouns, and affixed nouns have not been studied in details by the researchers.

The present study is conducted to investigate the learners' overgeneralization of nouns, particularly in singular/plural nouns and suffixed nouns in their progressive writing exercises. Moreover, progressive study is used to report what are the ways the learners overcome their overgeneralization. The results of the study would be based on the research questions written: (1) What are the overgeneralizations implemented by the learners in singular/plural nouns and suffixed nouns?, and; (2) Do the learners can recover their overgeneralization?.

\section{METHOD}

\section{The participants}

The study included three students of IELTS course as the participants in which their writing exercises were becoming the data of the study. The names of the participants are Henry, Hendriko, and Aditya. Those students were in the level class of 4.5 that the level itself is decided from the placement tests done by them before they join the class. At that time, the participants were in the same level of senior high school, grade 12, and three of them were planning to study overseas after graduating the high school. Hence, they decided to join the IELTS class in order to pass the IELTS exam as part of the requirement of overseas students. The course class was semi-private where it was going on for six months and it was already over. The materials they learned consisted of four languages skills; listening, reading, writing, and speaking. Writing material was conducted for 20 meetings including writing test. There are two types of writing materials in IELTS course, they are: 1.) part 1, 10 meetings, contains for report text of several kinds of graphs and figures such as line graph, bar graph, pie chart, and tables; 2.) part 2, 10 meetings, contains 
for argumentative texts of certain current issues as the topic cases. In this study, exercises taken for the data were part 1, the report text which commonly consisted of 250 words.

The data were collected at Future School of English (FSOE). It is an English course that focuses on the International English exam course such as International English Language Testing System (IELTS), and Test of English as a Foreign Language (TOEFL). The data were taken in the FSOE branched in Muara Karang while the headquarter is at Kelapa Gading.

The data were collected through meeting up the teacher who taught the students and asked her to show her collection of students writing exercises. After sorting the writings based on the materials they have learned, it had been chosen to pick up only three writing text for three different materials, line graph, bar graph, and pie chart. Those materials were chosen because they had similar kinds of grammatical patterns, yet, each of them had their own differences in vocabulary. Then differences were possible to appear because the vocabulary that the students should mention were different based on what happen on the graph.

Moreover, the materials were taught in sequential period which the first material to be taught was line graph, the second one was bar graph, and the last material is pie chart. After finishing each of materials, the teacher gave the writing exercises as their output of learning. The line graph exercise was done in week 1, the bar graph was at week 3, and the pie chart was in the week of 5 . It is appropriate with the purpose of the study where progressive exercises was chosen to examine whether the participants can overcome their problem in overgeneralization or not, and whether there is any difference between the first exercise with the others.
The data were analyzed by collecting all nouns that the participants produced in the writing and then sorting them according to the singular/plural nouns and suffix nouns. After sorting them, the data were analyzed based on the generalization they made which was considered appropriate and the overgeneralization which was considered inappropriate. The total numbers of both data were counted into percentage by dividing them each other and multiplying it with $100 \%$. The numbers then being compared each other to get the answer of the research questions. The results were displayed by the graphs that consisted of: 1.) the total number of singular/plural nouns and suffixed nouns; and 2.) the percentage of overgeneralization in singular/plural nouns and suffixed nouns. The graph were divided into week 1 (line graph), week 3 (bar graph), and week 5 (pie chart)

\section{FINDINGS AND DISCUSSION}

The results of the study were based on the purpose of the study which it tried to investigate the students' overgeneralizations and students' recoveries from overgeneralization. To conduct it, the data were examined their singular/plural production and suffixed production in their writing to determine the overgeneralization they made and the solution they decided to overcome their overgeneralization. The order of the findings was started from the singular/plural nouns followed by the suffixed nouns.

\section{Singular/plural nouns}

There were many singular/plural nouns that the participants produced in their writings and it was considered that they had sufficient knowledge of it. It is clearly seen in the graph that reporting the numbers of singular/plural nouns produced by the participant below: 
Table 1: Singular/plural nouns produced by the participants in their writings

\begin{tabular}{lrrr}
\hline & $\begin{array}{l}\text { Line graph } \\
\text { (week 1) }\end{array}$ & $\begin{array}{l}\text { Bar graph } \\
\text { (week 3) }\end{array}$ & $\begin{array}{l}\text { Pie chart } \\
\text { (week 5) }\end{array}$ \\
\hline Henry & 8 & 15 & 26 \\
Aditya & 3 & 13 & 17 \\
Hendriko & 15 & 36 & 40 \\
\hline
\end{tabular}

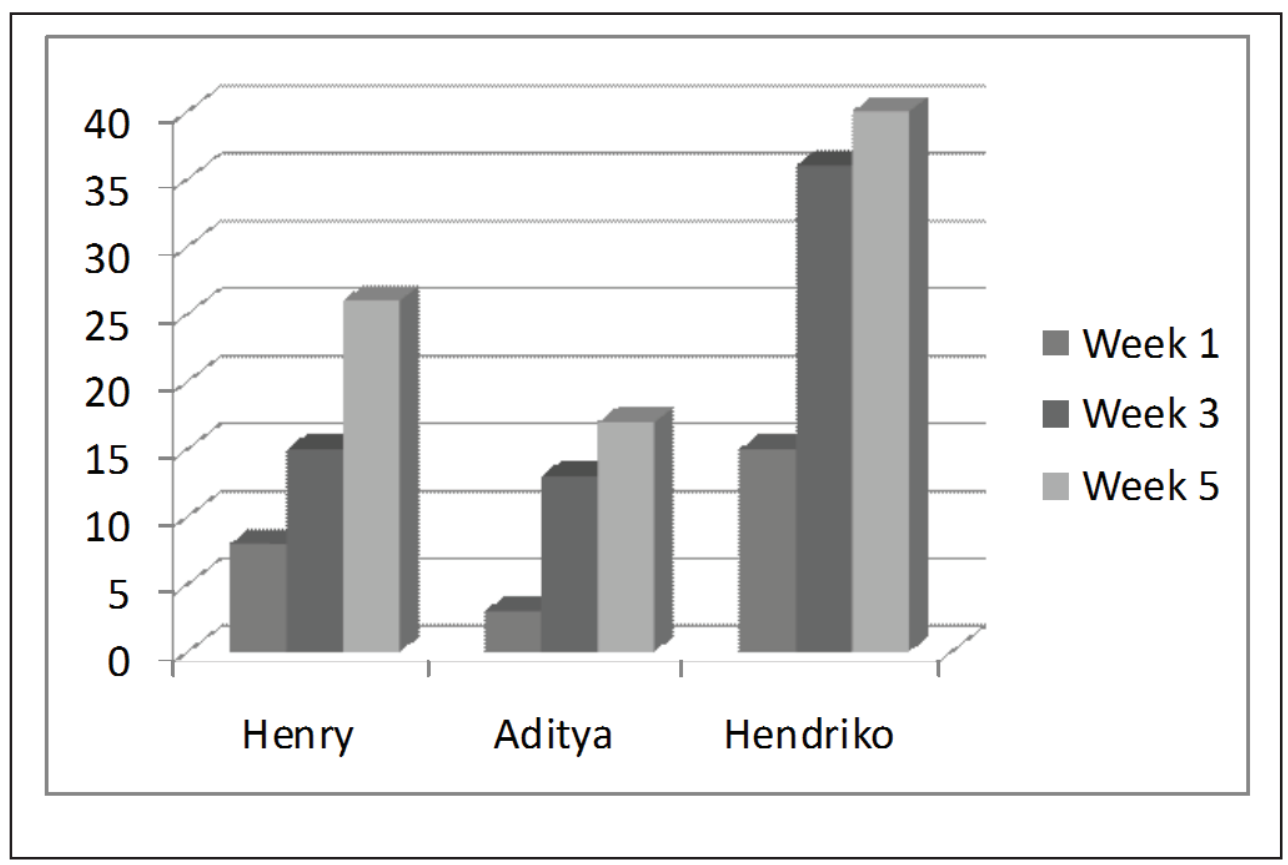

Figure1: The numbers of singular/plural noun produced by the participants

From the graph above, it is clearly seen that during the time, they produced singular/plural nouns more frequently. At the end of the week, the entire participants produced more than 15 nouns in one text. More over, Hendriko had the biggest number of singular/plural nouns production with 40 words at week 5 . Meanwhile, aditya was having the least number of nouns. The common overgeneralization made by the participants was from countable and uncountable nouns. Fro instance, they sometime misunderstood the uncountable noun of information with changing it into informations and the plural people with peoples.

To find out whether the participant can overcome their overgeneralization, the next result was the percentage of overgeneralization of singular/plural nouns created by the participants. 
Table 2: The percentage of overgeneralization of singular/plural nouns created by the participants

\begin{tabular}{lrrr}
\hline & \multicolumn{1}{l}{$\begin{array}{l}\text { Line graph } \\
\text { (Week 1) }\end{array}$} & $\begin{array}{l}\text { Bar Graph } \\
\text { (Week 3) }\end{array}$ & \multicolumn{1}{l}{$\begin{array}{l}\text { Pie Chart } \\
\text { (week 5) }\end{array}$} \\
\hline Henry & $12.50 \%$ & $13.30 \%$ & $11.55 \%$ \\
Aditya & $0 \%$ & $46.15 \%$ & $0 \%$ \\
Hendriko & $20 \%$ & $36.11 \%$ & $66.60 \%$ \\
\hline
\end{tabular}

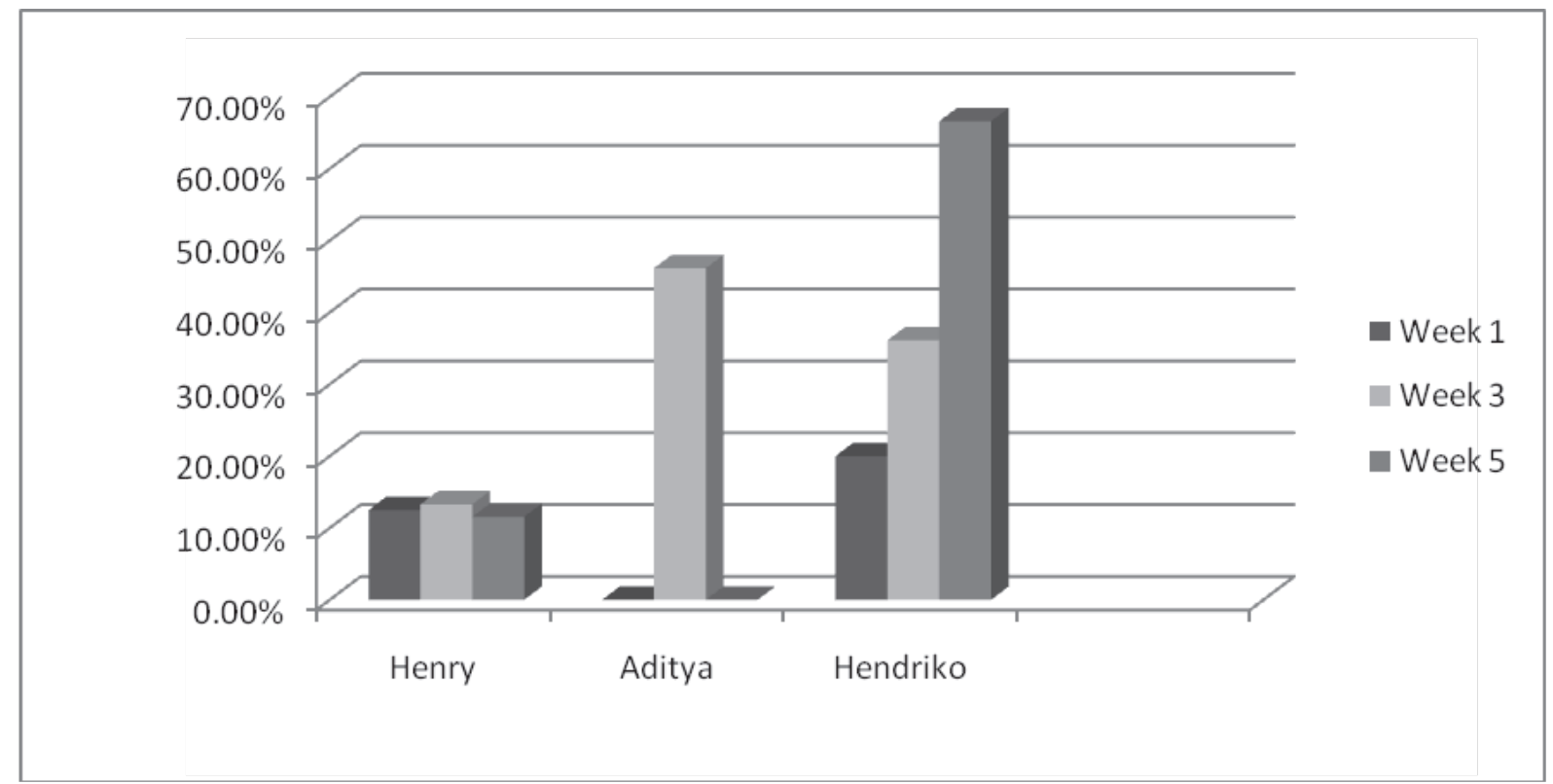

Figure 2: The percentage of overgeneralization in singular/plural nouns produced by the participants

It can be seen from the graph and table that each of the participants had different progress of overgeneralization production. There was no significant progress of Henry, while Aditya had no problem with overgeneralization with zero percent in the first and fifth week. Hendriko, on the other hand, made no progress in recovering his overgeneralization. On his last week, he made the highest percentage of overgeneralization in singular/plural nouns.

\section{Suffixed nouns}

In their writing, the participants also produced some suffixed nouns such as conclusion, information, etc. From the data, the way they produced the suffixed are derived from the verb and adjective. This first result revealed the numbers of suffixed nouns produced by the participants that is shown in the graphs as follows: 
Table 3: The result revealed the numbers of suffixed nouns produced by the participants

\begin{tabular}{lllll}
\hline & $\begin{array}{l}\text { Line Graph } \\
\text { (Week 1) }\end{array}$ & $\begin{array}{l}\text { Bar graph } \\
\text { (Week 3) }\end{array}$ & $\begin{array}{l}\text { Pie Chart } \\
\text { (Week 5) }\end{array}$ \\
\hline Aditya & 4 & 5 & 2 \\
Hendriko & 1 & 3 & 1 \\
Henry & 4 & 4 & 2 \\
\hline
\end{tabular}

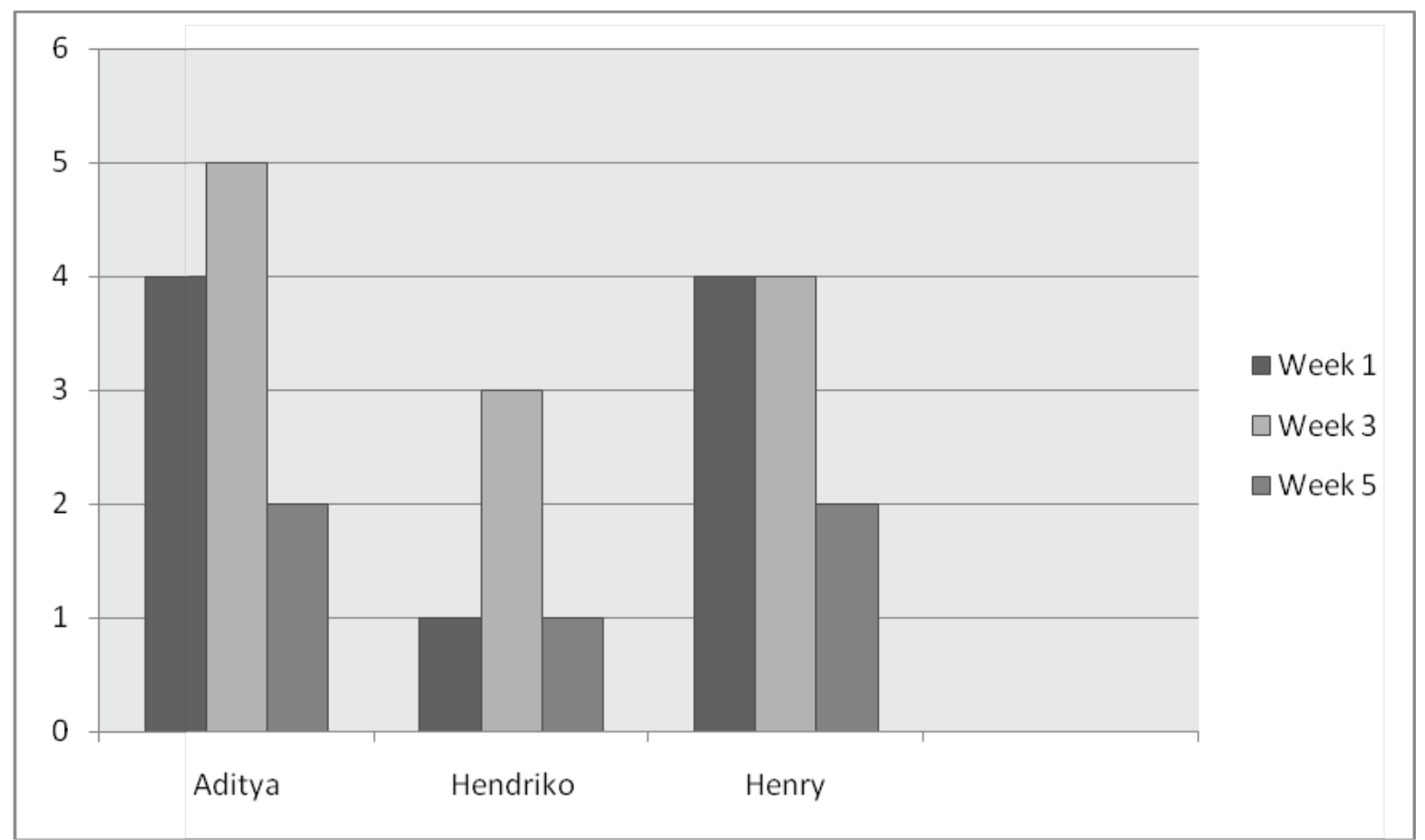

Figure 3: The numbers of suffixed noun produced by the participants

From the graph, it can be seen that during the time, the numbers of suffixed nouns that the participants produced were dynamic. First, it is clear that they mostly created more nouns in the third week. On the contrary, all participants produced suffixed nouns less frequent in the week five than other weeks. They become more careful and selective in mentioning the suffixed noun in the last week. The second chart demonstrates the percentage of overgeneralization of the suffixed nouns produced by the participants.

Table 4: The result revealed the numbers of suffixed nouns produced by the participants

\begin{tabular}{lrrr}
\hline & \multicolumn{1}{l}{$\begin{array}{l}\text { Line Graph } \\
\text { (Week 1) }\end{array}$} & \multicolumn{1}{l}{$\begin{array}{l}\text { Bar Graph } \\
\text { (Week 3) }\end{array}$} & \multicolumn{1}{l}{$\begin{array}{l}\text { Pie Chart } \\
\text { (Week 5) }\end{array}$} \\
\hline Aditya & $25.00 \%$ & $16.00 \%$ & $0.00 \%$ \\
Hendriko & $0.00 \%$ & $44.00 \%$ & $100.00 \%$ \\
Henry & $25.00 \%$ & $11.00 \%$ & $25.00 \%$ \\
\hline
\end{tabular}




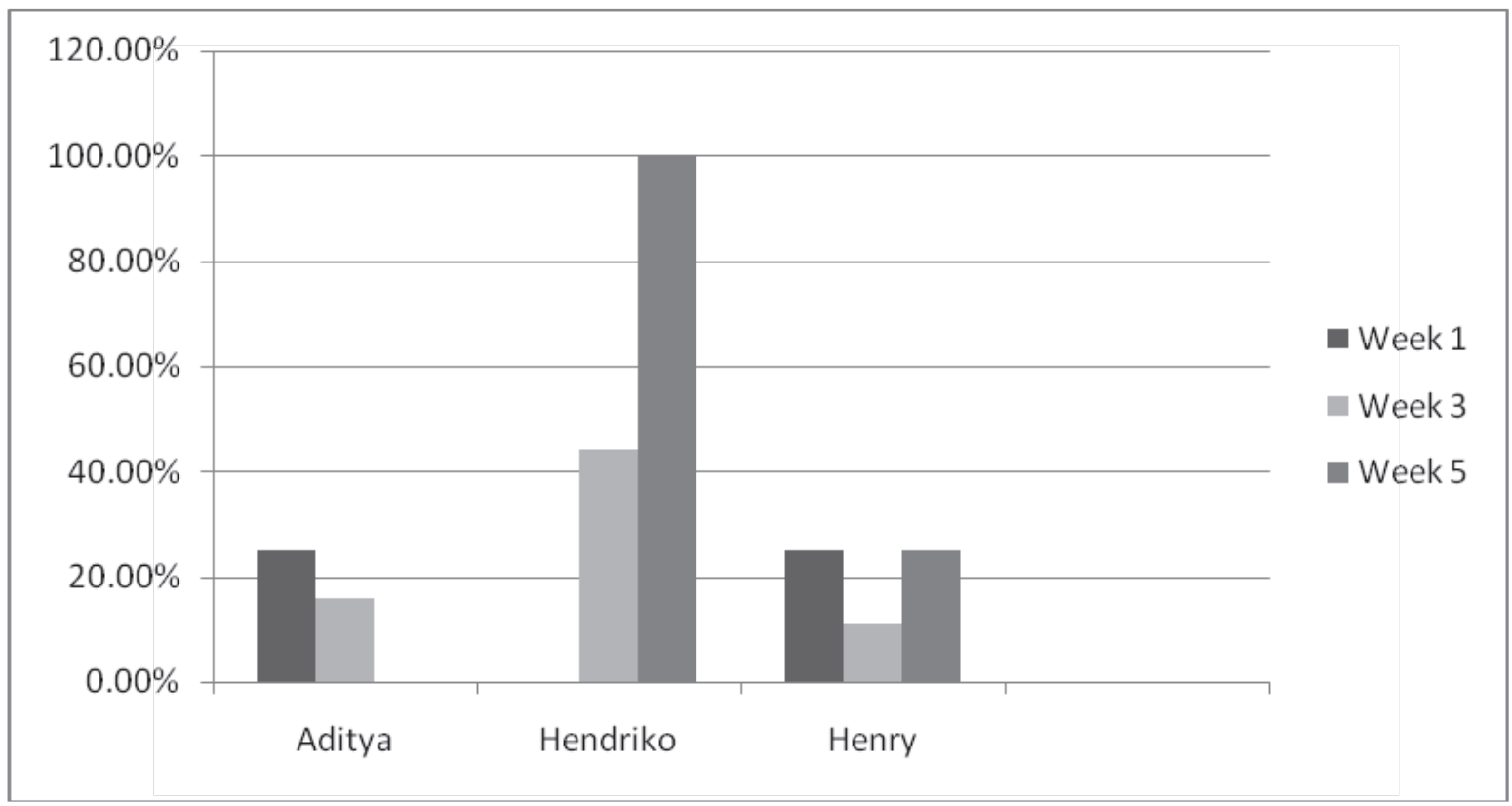

Figure 4: The percentage of overgeneralization in suffixed nouns produced by the participants

It is clearly seen that the way the participant recovered from overgeneralization were varied. Aditya had the least percentage of overgeneralization. At the end of the week, he did not produce any overgeneralization. On the other hand, Hendriko created the most significant difference during the week and had the biggest number of overgeneralization in suffixed nouns. Meanwhile, Henry produced the overgeneralization just above and below $25 \%$.

From the findings, it is reported that the participants produced singular/plural nouns more frequent during the time. It can be inferred that they were braver to produce singular/plural nouns during the period. It means that they had sufficient knowledge of singular/plural nouns so that mentioning more singular/plural nouns had not been the problem for them anymore even though they sometime overextended the rules with mismatching the plural $s$ in singular words and uncountable nouns.
However, the findings also reported that not all of them could recognize their overgeneralization and still created inappropriate words. While others could overcome it and recovered from overgeneralization, on the other hand, there was only little improvement during the weeks for another participant. It means that recovery form the overgeneralization in singular/plural may and may not be appeared for the language learners and not all of the learners have the ability to understand their overgeneralization and to repair what they have done wrong. It does not correspond with the theory of Onnis and Robert (2002) that "Language learners recover from these errors, in spite of the lack of negative evidence and the infinity of allowable constructions that remain unheard" (p. 1). It may only occur for the students who has the passion in English and has the motivation to get better in English proficiency.

The findings of the study found that during the time, the participants produced suffixed nouns less frequent. The fifth week became the least number of 
the suffixed word created by the participants. It can be inferred that they were being more careful and selective in producing the suffixed nouns. It could be because they were more aware of overextending the rules that they did not know whether this was appropriate or not to be applied. It finally reduced the chance for them to overgeneralize the suffixed noun.

On the other hand, the result of overgeneralization in suffixed nouns shows the same variety of recovery from the participants. There was a student who got better at the end of the week. Meanwhile, the other student was getting worse; another one just went back to the same time as the first week. It can be argued that the relational knowledge (Tyler \& Nagy, 1987) of the language learners may and may not be improved depending on the students themselves. Not all of the students can recover their overgeneralization from suffixed nouns even though they had taken time to learn English in informal classroom outside the school. Again, different passion and motivation of learning English may also influence the development of their interlanguage.

\section{CONCLUSION}

From the findings and discussions, it can be concluded that the learners' overgeneralizations cannot always be recovered and improved during the learning time. They still need more time and practices to enhance their proficiency of English even though they have gained sufficient knowledge of it. Singular/plural noun and suffixed nouns are the materials that most of the language learners have learned it since they were little. However, they still find it difficult to produce correct generalizations from both kinds of noun. Exercises and practices of English are needed to improve their proficiency while the teachers should give appropriate feedback to enhance their confidence in producing more English words.

There is also a weakness of the study that limits the reliability of the results. First, the complete evidence cannot be shown because the teacher who had the writing exercises did not have a complete collection of the exercise for all materials. Second, the study only depended on the students' production without observing more to the learning situation of the class so that it cannot be recognized the characters of each participant in the classroom.

The further research can be conducted according to final result of the study if other researchers can have a longitudinal study to discover the progress of their recovery of overgeneralization. The progressive study is necessary since in this study, the results shown varied evidence that is not really reliable to be trusted. Lastly, research instrument such as questionnaire is also needed to find out the passion and the motivation of the participants when they are in the class.

\section{REFERENCES}

Baker, C. L. (1979). Syntactic theory and the projection problem. Linguistic Inquiry, 10, 533-581.

Bowerman, M. 1982. Reorganizational processes in lexical and syntactic development. In E. Wanner \& L. Gleitman (Eds.), Language acquisition: The state of the art. Cambridge: university Press. Cabrera, M., \& Zabizarreta, M.L. (2005). Overgeneralization of causative and transfer in L2 Spanish and L2 English. 6th conference of the acquisitioan of Spanish and Portuguese as first and second language (pp. 1532). Somerville: Cascadilla Proceedings Project. 
Ellis, R. (1994) Learning and overgeneralization patterns in a connectionist model of German Plural The Study of Second Language Acquisition. Oxford: Oxford University Press.

Gass, S. M., \& Selinker, L. (2008). Second Language Acquisition: An Introductory Course: Taylor and Francis

Harakchiyska, T. (2011). Overgeneralization as a strategy for the acquisition of L1 and L2 noun, morphology (the category of number). Научни Трудове $\mathrm{Ha}$ Русенския Университет , 63 (50), 115-123.

Lightbown, P. M., \& Spada, N. (2006). How Languages Are Learned, 3rd edn., Oxford: Oxford University Press.

Li, P. (1996). Cryptotypes, meaning-form mapings, and overgeneralizations. Journal of Verbal Learning and Verbal Behavior , 1-17.
Onnis, L., Roberts, M., \& Chater, N. (2002). Simplicity: A cure for overgeneralization in language acquisition? conventry: University of Warwick.

Saidan, A. M. (2011). Linguistic overgeneralization: A case study. International Journal of academic research in Business and Social Science , 1, 184-194.

Tyler, A., \& Nagy, W. (1987). The acquisition of English Derivation morphology. Technical report (407), 1-38.

\section{ACKNOWLEDGMENTS}

I would like to thank my class mate, Novia Kusuma, who helped me in the way of analyzing the data and my IELTS students who took part in this research. 


\section{Appendices}

\section{Suffixed nouns table}

\begin{tabular}{|c|c|c|c|}
\hline & Line Graph (week 1) & Bar graph (week 3) & Pie Chart (week 5) \\
\hline \multirow[t]{4}{*}{ Aditya } & 1. Comparison & 1. Occupation & 1. Information \\
\hline & 2. Increasement $(\mathrm{x})$ & 2. Majority & 2. Shoppers \\
\hline & 3. Decreasement (x) & 3. A big differences ( $\mathrm{x}$ ) & \\
\hline & 4. conclusion & 4. workers & \\
\hline \multirow[t]{3}{*}{ Hendriko } & 1. Difference (x) (wrong & 1. Occupation & 1. Respondent \\
\hline & in the context, it & 2. Recruited (x) & \\
\hline & $\begin{array}{l}\text { supposed to be } \\
\text { adjective) }\end{array}$ & 3. The higher $(\mathrm{x})$ & \\
\hline \multirow[t]{4}{*}{ Henry } & 1. Information & 1. Comparison & 1. Respondant (x) \\
\hline & 2. Decreseament $(\mathrm{x})$ & 2. Occupation & 2. conclusion \\
\hline & 3. Increasement (x) & 3. The lowest (x) & \\
\hline & 4. conclusion & 4. The difference & \\
\hline
\end{tabular}

In week 1 , Henry only produced 8 singular and plural nouns altogether.

\begin{tabular}{lllll}
\hline No. & Nouns & Singular & Plural & Overgeneralization \\
\hline 1. & Informations & & $\mathrm{X}$ & $\mathrm{X}$ \\
2. & Rates & & $\mathrm{X}$ & \\
3. & People & & $\mathrm{X}$ & \\
4. & Rates & $\mathrm{X}$ & \\
5. & Rates & $\mathrm{X}$ & \\
6. & Opportunities & & & \\
7. & A graph & $\mathrm{X}$ & & \\
8. & A conclusion & $\mathrm{X}$ & & \\
\hline
\end{tabular}

Table 1: Participant 1, Week. 1

Participant 1: Henry

Week 3: Bar graph

Focus of the researcher: singular and plural nouns

\begin{tabular}{|c|c|c|c|c|}
\hline No. & Nouns & Singular & Plural & Overgeneralization \\
\hline 1. & Workers & & $\mathrm{X}$ & \\
\hline 2. & Types & & $\mathrm{X}$ & \\
\hline 3. & Workers & & $\mathrm{X}$ & \\
\hline 4. & Managers & & $\mathrm{X}$ & \\
\hline 5. & Senior officials & & $\mathrm{X}$ & \\
\hline 6. & Men workers & & $\mathrm{X}$ & $\mathrm{X}$ \\
\hline 7. & Female workers & & $\mathrm{X}$ & \\
\hline 8. & Female workers & & $\mathrm{X}$ & \\
\hline 9. & $\begin{array}{l}\text { Male and female } \\
\text { workers }\end{array}$ & & $\mathrm{X}$ & \\
\hline 10. & Female workers & & $\mathrm{X}$ & \\
\hline 11. & Male workers & & $\mathrm{X}$ & \\
\hline 12. & $\begin{array}{l}\text { Being machine } \\
\text { operator }\end{array}$ & & & $\mathrm{X}$ \\
\hline 13. & Female workers & & $\mathrm{X}$ & \\
\hline 14. & Male workers & & $\mathrm{X}$ & \\
\hline 15. & A conclusion & $\mathrm{X}$ & & \\
\hline
\end{tabular}


Participant 1: Henry

Week 5: A pie chart and a table

Focus of the researcher: singular and plural nouns

\begin{tabular}{|c|c|c|c|c|}
\hline No. & Nouns & Singular & Plural & Overgeneralization \\
\hline 1. & Two tables & & $\mathrm{X}$ & \\
\hline 2. & One pie chart & $\mathrm{X}$ & & \\
\hline 3. & $\begin{array}{l}\text { A new shopping } \\
\text { mall }\end{array}$ & $\mathrm{X}$ & & \\
\hline 4. & 200 respondants & & $\mathrm{X}$ & \\
\hline 5. & 51 respondants & & $\mathrm{X}$ & \\
\hline 6. & The shops & & $\mathrm{X}$ & \\
\hline 7. & 52 respondants & & $\mathrm{X}$ & \\
\hline 8. & Satisfied about & & $\mathrm{X}$ & \\
\hline & $\underline{\text { restaurants }}$ & & & \\
\hline 9. & 27 respondants & & $\mathrm{X}$ & \\
\hline 10. & $\begin{array}{l}\text { Comment about } \\
\text { shops }\end{array}$ & & $\mathrm{X}$ & \\
\hline 11. & 35 respondants & & $\mathrm{X}$ & \\
\hline 12. & $\begin{array}{l}\text { Comment about } \\
\text { restaurants }\end{array}$ & & $\mathrm{X}$ & \\
\hline 13. & Most respondants & & $\mathrm{X}$ & \\
\hline 14. & Respondants who.... & & $\mathrm{X}$ & \\
\hline 15. & Their shops & & $\mathrm{X}$ & \\
\hline 16. & More respondants & & $\mathrm{X}$ & \\
\hline 17. & With shops & & $\mathrm{X}$ & \\
\hline 18. & 26 respondants & & $\mathrm{X}$ & \\
\hline 19. & Restaurants & & $\mathrm{X}$ & \\
\hline 20. & 21 female & & $\mathrm{X}$ & $\mathrm{X}$ \\
\hline 21. & 5 male & & $\mathrm{X}$ & $\mathrm{X}$ \\
\hline 22. & The foods & & $\mathrm{X}$ & \\
\hline 23. & For female & & $\mathrm{X}$ & $\mathrm{X}$ \\
\hline 24. & A conclusion & $\mathrm{X}$ & & \\
\hline 25. & Shops & & $\mathrm{X}$ & \\
\hline 26. & Restaurants & & $\mathrm{X}$ & \\
\hline
\end{tabular}

Participant 2: Aditya

Week 1: Line graph

Focus of the researcher: singular and plural nouns

\begin{tabular}{lllll}
\hline No. & Nouns & Singular & Plural & Overgeneralization \\
\hline 1. & Jobless rates & & $\mathrm{X}$ & \\
2. & US jobless rate & $\mathrm{X}$ & & \\
3. & $\begin{array}{l}\text { Japan jobless } \\
\text { rate }\end{array}$ & $\mathrm{X}$ & & \\
\hline
\end{tabular}


Participant 2: Aditya

Week 3: Bar graph

Focus of the researcher: singular and plural nouns

\begin{tabular}{|c|c|c|c|c|}
\hline No. & Nouns & Singular & Plural & Overgeneralization \\
\hline 1. & $\begin{array}{l}\text { Male and female } \\
\text { workers }\end{array}$ & & $\mathrm{X}$ & \\
\hline 2. & A skilled traders & & & $\mathrm{X}$ \\
\hline 3. & $\begin{array}{l}\text { A big } \\
\text { differences }\end{array}$ & & & $\mathrm{X}$ \\
\hline 4. & $\begin{array}{l}\text { Male and female } \\
\text { employee }\end{array}$ & & $\mathrm{X}$ & $\mathrm{X}$ \\
\hline 5. & 5 percent & & & $\mathrm{X}$ \\
\hline 6. & Male workers & & $\mathrm{X}$ & \\
\hline 7. & Female workers & & $\mathrm{X}$ & \\
\hline 8. & $\begin{array}{l}\text { Skilled trade } \\
\text { occupation }\end{array}$ & $\mathrm{X}$ & & $\mathrm{X}$ \\
\hline 9. & $\begin{array}{l}\text { Machine } \\
\text { operative } \\
\text { occupation }\end{array}$ & & & $\mathrm{X}$ \\
\hline 10. & $\begin{array}{l}\text { Each } \\
\text { occupation }\end{array}$ & $\mathrm{X}$ & & \\
\hline 11. & $\begin{array}{l}\text { Managers and } \\
\text { senior official } \\
\text { occupation }\end{array}$ & & & $\mathrm{X}$ \\
\hline 12. & $\begin{array}{l}\text { The highest } \\
\text { number of } \\
\text { workers }\end{array}$ & $\mathrm{X}$ & $\mathrm{X}$ & \\
\hline 13. & $\begin{array}{l}\text { The total of } \\
\text { male and female } \\
\text { workers }\end{array}$ & $\mathrm{X}$ & $\mathrm{X}$ & \\
\hline
\end{tabular}

Participant 2: Aditya

Week 5: A pie chart and a table

Focus of the researcher: singular and plural nouns

\begin{tabular}{|c|c|c|c|c|}
\hline No. & Nouns & Singular & Plural & Overgeneralization \\
\hline 1. & Three tables & & $\mathrm{X}$ & \\
\hline 2. & $\begin{array}{l}\text { Different } \\
\text { information }\end{array}$ & & & \\
\hline 3. & The results & & $\mathrm{X}$ & \\
\hline 4. & $\begin{array}{l}\text { A new shopping } \\
\text { complex }\end{array}$ & $\mathrm{X}$ & & \\
\hline 5. & Shoppers & & $\mathrm{X}$ & \\
\hline 6. & $\begin{array}{l}34 \text { female } \\
\text { shoppers }\end{array}$ & & $\mathrm{X}$ & \\
\hline 7. & $\begin{array}{l}\text { Most of male } \\
\text { shoppers }\end{array}$ & & $\mathrm{X}$ & \\
\hline 8. & Male shoppers & & $\mathrm{X}$ & \\
\hline 9. & $\begin{array}{l}\text { Male and female } \\
\text { shoppers }\end{array}$ & & $\mathrm{X}$ & \\
\hline 10. & Shoppers & & $\mathrm{X}$ & \\
\hline 11. & Most of the & & $\mathrm{X}$ & \\
\hline
\end{tabular}


male shoppers

12. Only five male shoppers

13. Female shoppers

14. No comment shoppers

15. Most of shoppers

16. There are only $10 \%$ of the shoppers

17. 17 percent of $\mathrm{X}$

X

X

$\mathrm{X}$

X the shoppers

Participant 3: Hendriko

Week 1: Line graph

Focus of the researcher: singular and plural nouns

\begin{tabular}{|c|c|c|c|c|}
\hline No. & Nouns & Singular & Plural & Overgeneralization \\
\hline 1. & A job rates & & & $\mathrm{X}$ \\
\hline 2. & An work force & & & $\mathrm{X}$ \\
\hline 3. & $\begin{array}{l}\text { Unemployment } \\
\text { rates was } 7 \\
\text { percent }\end{array}$ & & & $\mathrm{X}$ \\
\hline 4. & The highest rate & $\mathrm{X}$ & & \\
\hline 5. & 6.4 percent & $\mathrm{X}$ & & \\
\hline 6. & 5.5 percent & $\mathrm{X}$ & & \\
\hline 7. & 5.6 percent & $\mathrm{X}$ & & \\
\hline 8. & 5.1 percent & $\mathrm{X}$ & & \\
\hline 9. & 4.9 percent & $\mathrm{X}$ & & \\
\hline 10. & 2.5 percent & $\mathrm{X}$ & & \\
\hline 11. & 4.2 percent & $\mathrm{X}$ & & \\
\hline 12. & 4.4 percent & $\mathrm{X}$ & & \\
\hline 13. & 4.5 percent & $\mathrm{X}$ & & \\
\hline 14. & 5 percent & $\mathrm{X}$ & & \\
\hline
\end{tabular}


Participant 2: Hendriko

Week 3: Bar graph

Focus of the researcher: singular and plural nouns

\begin{tabular}{|c|c|c|c|c|}
\hline No. & Nouns & Singular & Plural & Overgeneralization \\
\hline 1. & $\begin{array}{l}\text { Ther worker of } \\
\text { all gender } \\
\text { workers }\end{array}$ & & $\mathrm{X}$ & \\
\hline 2. & $\begin{array}{l}\text { Machine } \\
\text { operatives }\end{array}$ & & $\mathrm{X}$ & \\
\hline 3. & Skilled trades & & $\mathrm{X}$ & \\
\hline 4. & Manager & & & $\mathrm{X}$ \\
\hline 5. & Senior officials & & $\mathrm{X}$ & \\
\hline 6. & Professional & & & $\mathrm{X}$ \\
\hline 7. & $\begin{array}{l}\text { Associate } \\
\text { professional and } \\
\text { technical }\end{array}$ & & & $\mathrm{X}$ \\
\hline 8. & $\begin{array}{l}\text { Labores, catering } \\
\text { assistants and } \\
\text { sales }\end{array}$ & & $\mathrm{X}$ & \\
\hline 9. & $\begin{array}{l}\text { Customer } \\
\text { services }\end{array}$ & & $\mathrm{X}$ & \\
\hline 10. & $\begin{array}{l}\text { Administrative } \\
\text { and secretarial }\end{array}$ & & & $\mathrm{X}$ \\
\hline 11. & Personal service & & & $\mathrm{X}$ \\
\hline 12. & 20 percent & $\mathrm{X}$ & & \\
\hline 13. & Manager & $\mathrm{X}$ & & $\mathrm{X}$ \\
\hline 14. & Senior official & $\mathrm{X}$ & & $\mathrm{X}$ \\
\hline 15. & Professional & $\mathrm{X}$ & & $\mathrm{X}$ \\
\hline 16. & Technical & $\mathrm{X}$ & & $\mathrm{X}$ \\
\hline 17. & Labores & & $\mathrm{X}$ & \\
\hline 18. & $\begin{array}{l}\text { Catering } \\
\text { assistants }\end{array}$ & & $\mathrm{X}$ & \\
\hline 19. & Sales & & $\mathrm{X}$ & \\
\hline 20. & $\begin{array}{l}\text { Customer } \\
\text { services }\end{array}$ & & $\mathrm{X}$ & \\
\hline 21. & $\begin{array}{l}\text { Administrative } \\
\text { and secretarial }\end{array}$ & & & $\mathrm{X}$ \\
\hline 22. & Personal service & & & $\mathrm{X}$ \\
\hline 23. & 3 percents & & $\mathrm{X}$ & $\mathrm{X}$ \\
\hline 24. & Managers & & $\mathrm{X}$ & \\
\hline 25. & Skilled trades & & $\mathrm{X}$ & \\
\hline 26. & Senior officials & & $\mathrm{X}$ & \\
\hline 27. & 15 percent & $\mathrm{X}$ & & \\
\hline 28. & 13 percent & $\mathrm{X}$ & & \\
\hline 29. & 23 percent & $\mathrm{X}$ & & \\
\hline 30. & 3 percent & $\mathrm{X}$ & & \\
\hline 31. & 21 percents & & $\mathrm{X}$ & $\mathrm{X}$ \\
\hline
\end{tabular}


Participant 3: Hendriko

Week 5: A pie chart and a table

Focus of the researcher: singular and plural nouns

\begin{tabular}{|c|c|c|c|c|}
\hline No. & Nouns & Singular & Plural & Overgeneralization \\
\hline 1. & 3 categories & & $\mathrm{X}$ & \\
\hline 2. & 1 charts & & & $\mathrm{X}$ \\
\hline 3. & 2 tables & & $\mathrm{X}$ & \\
\hline 4. & $\begin{array}{l}\text { There are shops, } \\
\text { restaurants... }\end{array}$ & & $\mathrm{X}$ & \\
\hline 5. & Shops & & & \\
\hline 6. & 51 peoples & & $\mathrm{X}$ & $\mathrm{X}$ \\
\hline 7. & 82 peoples & & $\mathrm{X}$ & $\mathrm{X}$ \\
\hline 8. & 20 peoples & & $\mathrm{X}$ & $\mathrm{X}$ \\
\hline 9. & Males & & $\mathrm{X}$ & $\mathrm{X}$ \\
\hline 10. & Females & & $\mathrm{X}$ & $\mathrm{X}$ \\
\hline 11. & 27 peoples & & $\mathrm{X}$ & $\mathrm{X}$ \\
\hline 12. & 52 respondant & & $\mathrm{X}$ & $\mathrm{X}$ \\
\hline 13. & 21 males & & $\mathrm{X}$ & $\mathrm{X}$ \\
\hline 14. & 5 females & & $\mathrm{X}$ & $\mathrm{X}$ \\
\hline 15. & The restaurant & & $\mathrm{X}$ & $\mathrm{X}$ \\
\hline 16. & 35 peoples & & $\mathrm{X}$ & $\mathrm{X}$ \\
\hline 17. & 17 percent of & & $\mathrm{X}$ & $\mathrm{X}$ \\
\hline 18. & $\begin{array}{l}\text { respondant } \\
62 \text { percents of } \\
\text { people }\end{array}$ & & $\mathrm{X}$ & $\mathrm{X}$ \\
\hline 19. & $\begin{array}{l}10 \text { percent of } \\
\text { people }\end{array}$ & & $\mathrm{X}$ & \\
\hline 20. & $\begin{array}{l}11 \text { percent of } \\
\text { people }\end{array}$ & & $\mathrm{X}$ & \\
\hline 21. & $\begin{array}{l}\text { The respondant } \\
\text { is satisfied }\end{array}$ & & $\mathrm{X}$ & $\mathrm{X}$ \\
\hline
\end{tabular}

